\title{
FENOMENA JUDI KARTU REMI DI DUSUN MEDANG DESA SAMPUNG KECAMATAN SAMPUNG KABUPATEN PONOROGO
}

\author{
Prima Andika Saputra, I Dewa Putu Eskasasnanda, dan Sukamto \\ E-mail: primaandikasaputra@gmail.com \\ Pendidikan IImu Pengetahuan Sosial Fakultas IImu Sosial \\ Universitas Negeri Malang
}

\begin{abstract}
Abstrak
Penelitian ini bertujuan untuk mengetahui apa yang melatarbelakangi perjudian kartu remi yang berada di Dusun Medang Desa Sampung Kecamatan Sampung. Penelitian ini menggunakan pendekatan kualitatif dengan jenis penelitian deskriptif (descriptive research). Sumber data yang digunakan yaitu sumber primer dan sumber sekunder. Pengumpulan data dalam penelitian ini yaitu dengan observasi, wawancara dan dokumentasi dengan teknik analisis menggunakan model interaktif Miles dan Huberman. Tahap penelitian yang dilakukan yaitu tahap persiapan, pelaksanaan dan pelaporan. Hasil penelitian faktor yang melatarbelakangi pelaku melakukan judi kartu remi yang terbesar adalah faktor teman atau lingkungan.

Kata kunci: Fenomena, Perjudian, Kartu Remi
\end{abstract}

Abstract

This study aims to determine what is the background of playing playing cards in Dusun Medang, Sampung Village, Sampung District. This study uses a qualitative approach with descriptive research type (descriptive research). The data sources used are primary and secondary sources. Data collection in this study is by observation, interviews and documentation with analysis techniques using the interactive model of Miles and Huberman. The research stage carried out is the preparation, implementation and reporting stages. The results of the research, the factors behind the biggest players in playing card gambling are friends or the environment.

Keywords: The Phenomenon, Gambling, Playing Card

\section{Pendahuluan}

Masyarakat merupakan suatu sistem yang terbentuk karena hubungan anggotaanggotanya. Hubungan dalam kehidupan masyarakat tersebut dinamakan sebagai sistem kemasyarakatan yang merupakan suatu kenyataan objektif yang mandiri, bebas dari individuindividu yang merupakan anggota-anggotanya. Kehidupan bermasyarakat seseorang tidak dapat lepas dari norma yang mengaturnya. Apabila masing-masing anggota masyarakat mentaati dan menjalankan hidup sesuai nilai dan norma yang berlaku di masyarakat maka kehidupan masyarakat akan menjadi tentram, nyaman dan damai. Namun pada kenyataannya kehidupan masyarakat aman tenteram ini seringkali terganggu karena perilaku menyimpang sebagian anggota masyarakat. Perilaku kelompok manusia yang menyimpang dari norma ini lebih dikenal dengan penyimpangan sosial.

Fenomena Judi Kartu Remi di Dusun Medang Desa Sampung Kecamatan Sampung Kabupaten Ponorogo | Prima Andika Saputra, I Dewa Putu Eskasasnanda dan Sukamto 
Salah satu bentuk penyimpangan sosial yang ada di dalam masyarakat adalah judi kartu remi. Judi kartu remi merupakan kegiatan yang mempertaruhkan uang pada permainan kartu dalam suatu arena. Judi remi dapat dikatakan sebagai penyimpangan sosial karena melanggar norma yang berlaku di masyarakat terutama norma hukum. Di dalam norma hukum pada pasal 303 ayat 3 KUHP diatur bahwa berjudi dan bertaruh dilarang karena membuat orang menjadi malas, tidak mengenal rasa malu. Berjudi juga apabila modalnya habis penjudi bisa menjadi kalap dan bisa merampas hak milik orang lain (Kartono, 2014:81).

Prinsip bermain judi sebagaimana ditetapkan di dalam Pasal 303 KUHP diartikan sebagai tiap-tiap permainan, yang kemungkinan akan menang pada umumnya bergantung kepada untunguntungan saja, juga kalau kemungkinan akan menang itu bertambah besar karena si pemain lebih pandai atau lebih hafal. Main judi meliputi juga segala perjanjian pertaruhan tentang keputusan perlombaan atau permainan lain yang tidak diadakan oleh mereka yang turut berlomba atau main itu, demikian juga segala pertaruhan lainnya.

Diketahui bahwa fenomena judi kartu remi banyak terjadi di masyarakat, salah satunya di Dusun Medang Desa Sampung. Judi kartu remi di Dusun Medang marak terjadi karena lokasi Desa Sampung dirasa aman untuk melaksanakan judi kartu remi.
Kondisi Dusun Medang Desa Sampung yang jauh dari kota dan kantor polisi, membuat oknum dalam masyarakat lebih leluasa untuk melaksanakan judi kartu remi. Masyarakat menerima keberadaan pemain judi kartu remi karena merupakan budaya dalam masyarakat. Judi kartu remi biasa dilakukan oleh oknum masyarakat ketika memiliki waktu luang di malam hari. Berjudi remi adalah permainan yang menyenangkan untuk mengisi waktu senggang. Tempat yang digunakan untuk arena judi kartu remi juga dipilih jauh dari jalan raya agar terhindar dari polisi. Judi kartu remi ini juga sering dilakukan ketika acara pesta pernikahan maupun acara selamatan kelahiran bayi.

Perkembangan judi kartu remi di Dusun Medang cukup meresahkan. Hal tersebut karena banyak anak dan remaja yang sering terlihat berbaur dalam area judi. Dikhawatirkan seiring berjalannya waktu, banyak anak dan remaja tersebut akhirnya masuk ke dalam permainan judi kartu remi tersebut. Keterlibatan anak dan remaja dalam permainan judi biasanya dimulai dari mereka melihat judi, diminta menjaga situasi keamanan judi, dan selanjutnya mempertaruhkan uang dan ikut melakukan permainan judi kartu remi.

Berdasarkan uraian latar belakang di atas, peneliti tertarik mencari tahu bagaimana pelaksanaan judi kartu remi, apa faktor-faktor yang melatarbelakangi masyarakat malakukan judi kartu remi dan, apa dampak judi kartu remi terhadap 
kehidupan sosial keluarga para pelaku judi remi. Peneliti memilih Dusun Medang Desa Sampung karena masyarakat di desa ini banyak yang memilih judi kartu remi meskipun ada judi yang lain. Dari permasalahan di atas maka judul penelitian ini adalah "Fenomena Judi Kartu Remi di Dusun Medang Desa Sampung Kecamatan Sampung Kabupaten Ponorogo".

\section{Metode}

Penelitian ini dilakukan di Dusun Medang Desa Sampung, Kecamatan Sampung Kabupaten Ponorogo, Provinsi Jawa Timur. Lokasi ini dipilih karena alasan kemudahan mencari informasi, di Dusun Medang banyak masyarakat yang melakukan judi kartu remi. Dan masih belum ada yang meneliti tentang perjudian kartu remi yang ada di Dusun Medang Desa Sampung. Secara umum penelitian ini dilakukan di Dusun Medang Desa Sampung. Lokasi penelitian bisa dilakukan di tempat-tempat perjudian dan di acara pernikahan maupun tempat lahiran.

Penelitian tentang Fenomena Judi Kartu Remi di Dusun Medang Desa Sampung Kecamatan Sampung ini telah dilaksanakan selama 2 bulan yaitu bulan April sampai Mei 2019. Subjek penelitian dibutuhkan oleh peneliti dalam mencari informasi dan data mengenai fokus penelitian. Data yang diperoleh nantinya akan digunakan untuk menggambarkan fenomena judi kartu remi yang berada di Dusun Medang Desa Sampung Kecamatan
Sampung Kabupaten Ponorogo.

Penelitian ini menggunakan pendekatan kualitatif yaitu penelitian yang dilakukan dalam kondisi tertentu dalam kehidupan nyata di lapangan dan pendekatan kualitatif ini tidak berhubungan dengan angka-angka statistika. Melalui pendekatan kualitatif peneliti menjelaskan tentang pelaku judi kartu remi di Dusun Medang Desa Sampung Kecamatan Sampung Kabupaten Ponorogo. Menurut Indranata (2008:5) menjelaskan bahwa penelitian kualitatif adalah suatu rangkaian kegiatan atau proses menjaring informasi, dari kondisi sewajarnya dalam kehidupan suatu subyek, dihubungkan dengan suatu pemecahan masalah, baik dari sudut pandang teoritis maupun praktis. Penelitian kualitatif lebih mementingkan proses daripada hasil, sehingga dibutuhkan suatu ketajaman analisis, objektivitas, sistematik, sehingga didapat ketepatan data dari suatu gejala atau fenomena.

Menurut Azwar (2015:6) penelitian deskriptif melakukan analisis hanya sampai pada taraf deskripsi yaitu menganalisis dan menyajikan hasil penelitian berdasarkan fakta secara sistematik sehingga dapat lebih mudah untuk dipahami dan disimpulkan. Penelitian yang bersifat deskriptif tersebut mempunyai tujuan untuk memberikan gambaran atau menguraikan tentang sifat-sifat untuk suatu individu, kelompok, atau pun keadaan dan obyek tertentu secara tepat, dalam hal ini yang berkaitan dengan kegiatan judi kartu remi.

Fenomena Judi Kartu Remi di Dusun Medang Desa Sampung Kecamatan Sampung Kabupaten Ponorogo | Prima Andika Saputra, I Dewa Putu Eskasasnanda dan Sukamto 
Jadi dalam penelitian ini lebih mementingkan membahas mengenai karakteristik, tahapan, faktor yang melatarbelakangi dan dampak yang terjadi pada perjudian kartu remi. Oleh karena itu, Penelitian menggunakan deskriptif kualitatif untuk mengetahui tentang "Fenomena Judi Kartu Remi di Dusun Medang Desa Sampung".

Sumber data dalam penelitian adalah subjek data yang diperoleh. Sumber data yang digunakan dalam penelitian ini adalah data primer dan data sekunder. Data primer adalah data yang diperoleh langsung di lokasi penelitian, melalui pengamatan langsung di lapangan dan melalui proses wawancara dengan informan. Adapun data sekunder adalah data yang diperoleh dari studi literatur serta data yang berasal dari arsip atau dokumen (Moleong, 2004:157).

Data yang dikumpulkan oleh peneliti bersumber dari narasumber atau informan yang memiliki keterlibatan langsung dengan kegiatan judi kartu remi. Peristiwa atau aktivitas yang berkaitan dengan maksud adalah peneliti menyaksikan secara langsung pelaksanaan judi mulai dari persiapan sampai selesai. Tempat atau lokasi yang berisi informasi mengenai kondisi peristiwa aktivitas pelaksanaan judi kartu remi. Dokumen atau arsip yang dimaksud dapat berupa rekaman dan dokumen tertulis.

Data primer merupakan data yang langsung diperoleh dari subjek peneliti yang diwawancarai, data tersebut dapat berupa kata-kata dan tindakan. Peneliti melakukan wawancara dan observasi di lokasi penelitian yang ditentukan. Kata-kata dan tindakan informan sumber data utama. Sumber data utama ditulis, direkam, dan didokumentasikan. Sumber data primer diperoleh dari sejumlah narasumber yang merupakan pelaku judi kartu remi atau pernah melakukan judi kartu remi.

Pemilihan informan menggunakan teknik Snowball yaitu teknik penentuan informan yang mana digunakan apabila jumlah informan yang diketahui hanya sedikit. Dari informan yang sedikit tersebut peneliti mencari informasi lain dari yang dijadikan informan terdahulu, sehingga semakin lama jumlah informan semakin banyak. Informan dalam penelitian ini dibagi menjadi dua yakni informan pendukung dan informan kunci. Informan pendukung dalam penelitian ini adalah orang yang memiliki tempat yang digunakan sebagai tempat judi kartu remi. Informan kunci adalah para pelaku judi kartu remi.

Informan penelitian ini dipilih berdasarkan kriteria tertentu yang sesuai dengan tujuan penelitian, diantaranya yaitu:

a. Berjenis kelamin laki-laki.

b. Pernah atau sedang bermain judi kartu remi.

c. Bersedia menjadi subjek penelitian.

d. Sedang menetap di Dusun Medang Desa Sampung.

Sumber data kedua adalah sumber

Fenomena Judi Kartu Remi di Dusun Medang Desa Sampung Kecamatan Sampung Kabupaten Ponorogo | Prima Andika Saputra, I Dewa Putu Eskasasnanda dan Sukamto 
data sekunder yang merupakan sumber data yang didapat dengan cara tidak langsung. Sumber data ini tidak bisa diabaikan meskipun merupakan sumber kedua, karena bahan tambahan yang digunakan dalam penulisan ini berasal dari buku dan majalah ilmiah, sumber dari arsip, dokumen pribadi, dan dokumen resmi yang berkaitan dengan tema ini yakni judi khususnya judi kartu remi.

Prosedur pengumpulan yang digunakan dalam penelitian ini adalah menggunakan observasi partisipatif pasif. Peneliti datang di tempat kegiatan yang diamati, tetapi tidak ikut terlibat dalam kegiatan tersebut. Teknik pengumpulan data dengan observasi digunakan bila, penelitian berkenaan dengan perilaku manusia, proses kerja, gejala-gejala alam dan responden yang diamati tidak terlalu besar (Sugiyono, 2015:203). Menurut Soehartono (2008:69) observasi merupakan kegiatan pengamatan yang lebih mengandalkan indera penglihatan. Dengan observasi maka data yang diperoleh akan lebih lengkap, tajam, dan sampai mengetahui pada tingkat makna dari setiap perilaku yang tampak pada informan. Namun teknik observasi juga ada kekurangan nya. Kekurangan dari teknik observasi ini adalah, apabila peneliti tidak cermat dalam melakukan observasi maka data yang diperoleh kurang lengkap. Teknik observasi ini peneliti menggunakan alat bantu kamera, alat perekam suara sebagai alat perekam suara dan catatan sebagai instrumennya.

Wawancara digunakan sebagai teknik pengumpulan data apabila peneliti ingin mengetahui hal-hal yang mendalam yang ingin digali dari informan (Sugiyono, 2015:317). Wawancara dilakukan berfungsi untuk menggali informasi dari informan melalui percakapan yang dilakukan secara tatap muka dengan cara mengajukan pertanyaan berdasarkan tujuan tertentu. Sedangkan menurut Nasution (2001:113) menyatakan wawancara adalah suatu bentuk komunikasi verbal jadi semacam percakapan yang bertujuan memperoleh informasi. Jenis wawancara yang digunakan dalam penelitian ini adalah wawancara terstruktur yakni menggunakan pendekatan petunjuk umum wawancara dengan membuat instrumen wawancara terlebih dahulu. Petunjuk pokok ini hanyalah berisi petunjuk untuk menjaga agar pokok-pokok yang direncanakan dapat seluruhnya tercakup. Wawancara terstruktur dilakukan terhadap informan yaitu pelaku judi kartu remi. Sebelum melakukan wawancara terhadap informan kunci, terlebih dahulu peneliti melakukan wawancara terhadap instrumen pendukung.

Dokumentasi adalah setiap bahan ataupun non tulis seperti foto. Hasil penelitian dari observasi dan wawancara lebih kredibel atau dapat dipercaya apabila didukung oleh dokumentasi dari obyek maupun subyek penelitian (Sugiyono, 2015:329). Dokumentasi ini merupakan 
studi pelengkap yang digunakan untuk melengkapi penggunaan metode observasi dan wawancara yang telah dilakukan sebelumnya.

Dokumentasi dalam penelitian ini, penelitian menggunakan berbagai sumber buku, artikel, jurnal, rekaman yang diambil pada saat wawancara dan beberapa foto yang diambil ketika observasi dan wawancara dengan informan. Data yang terkumpul melalui teknik dokumentasi dalam penelitian tentang pelaku judi kartu remi yaitu berupa foto dan tulisan.

Model analisis yang digunakan dalam penelitian ini adalah model Miles dan Huberman. Menurut Miles dan Huberman (2014:16-20) "dalam penelitian kualitatif metode analisis data yang digunakan adalah model analisis interaktif. Model analisis interaktif ini dilakukan dengan empat langkah analisis data kualitatif, yaitu pengumpulan data, reduksi data, penyajian data, dan verifikasi. Ada empat tahapan yang digunakan untuk menganalisis data yang diperoleh dalam penelitian ini, antara lain:

1. Pengumpulan Data

Kegiatan pengumpulan data dilakukan melalui wawancara dengan informan penelitian, observasi dan dokumentasi. Data yang dihasilkan masih bersifat kasar, sehingga diperlukan proses lagi sebelum digunakan. Pengumpulan data ini peneliti memberi garis besar pada pokok penelitian. Pokok-pokok informasi yang diperoleh dari hasil wawancara antara lain mengenai karakteristik pemain judi kartu remi, latar belakang masyarakat melakukan judi kartu remi, dampak judi terhadap kehidupan sosial ekonomi keluarga pelaku judi kartu remi.

2. Reduksi Data

Reduksi data adalah kegiatan penggolongan, pemilihan, dan penyederhanaan data yang diperoleh di lapangan (Miles dan Huberman, 2014:16). Tahap reduksi data adalah tahap dimana kita merangkum, memilih hal-hal yang pokok, memfokuskan pada hal-hal yang terpenting. Dalam penelitian ini peneliti mencatat hasil wawancara dengan informan menggunakan catatan wawancara, yang dicatat hanya hal-hal pokok yang penting, peneliti juga mencari data melalui dokumentasi, selain itu peneliti juga membuat catatan observasi. Data yang diperoleh dari lapangan baik dari hasil wawancara, observasi, maupun dokumentasi yang telah terkumpul tersebut dipilih, dirangkum, dan disusun secara sistematis sesuai dengan tema masingmasing sehingga dapat memudahkan peneliti dalam penyusunan laporan.

3. Penyajian Data

Langkah selanjutnya adalah penyajian data. Penyajian data dilakukan dalam bentuk teks-teks yang bersifat naratif (Miles dan Huberman, 2014:17). Dalam penelitian kualitatif, penyajian data bisa dilakukan dalam bentuk uraian singkat, bagan, hubungan antar kategori, dan sejenisnya. Dalam penelitian ini penyajian 
data disajikan dalam bentuk narasi.

4. Penarikan Kesimpulan/Verifikasi Data

Langkah terakhir dalam penelitian adalah penarikan kesimpulan. Menarik kesimpulan/Verifikasi data merupakan kegiatan menarik makna-makna dari data yang sudah terkumpul dari hasil penelitian yang sudah dilakukan. Data yang sudah terkumpul diuji kebenarannya, kekokohannya, dan kecocokannya (Miles dan Huberman, 2014:19). Setelah peneliti memaparkan data dari hasil fakta di lapangan, selanjutnya peneliti menarik kesimpulan untuk menjawab rumusan masalah yang telah disusun. Kesimpulan dalam penelitian kualitatif merupakan temuan baru yang sebelumnya belum pernah ada.

Tahap-tahap Penelitian yang dilakukan melalui beberapa tahapan yaitu tahap persiapan, tahap rancangan penelitian, tahap pelaksanaan, dan tahap pelaporan.

1. Tahap Persiapan

Tahap persiapan ini peneliti membuat dan menyiapkan peralatan yang digunakan dalam observasi di lapangan. Hal yang disiapkan adalah pedoman wawancara, alat tulis dan alat untuk merekam. Peneliti juga menyiapkan diri sebelum melakukan penelitian.

2. Tahap Rancangan Penelitian

Tahap ini peneliti menentukan pedoman yang digunakan dalam melakukan penelitian. Pedoman penelitian dapat berupa petunjuk yang digunakan dalam melakukan pengumpulan data, analisis data, dan pengecekan keabsahan data.

3. Tahap Pelaksanaan

Tahap pelaksanaan peneliti terjun langsung ke lapangan untuk melakukan pengumpulan data. Pengumpulan data dilakukan berdasarkan prosedur pengumpulan data yang telah direncanakan. Data yang telah dikumpulkan kemudian dianalisis dan direduksi. Tahap terakhir dari pelaksanaan adalah pengelompokan data yang diperoleh melalui penelitian.

\section{Tahap Pelaporan}

Tahap pelaporan menyusun hasil penelitian yang telah dikumpulkan dalam bentuk paparan data. Selanjutnya peneliti membahas dalam bab pembahasan disertai dengan teori yang mendukung paparan data. Pembuatan laporan penelitian meliputi pendahuluan, landasan teori, metode penelitian, paparan data, pembahasan, penutup dan daftar rujukan serta lampiran. Sesuai dengan pedoman yang berlaku di Universitas Negeri Malang untuk menjadi syarat akhir kelulusan.

\section{Hasil dan Pembahasan}

Faktor yang melatarbelakangi pemain melakukan judi kartu remi di Dusun Medang Desa Sampung Kecamatan Sampung :

1. Faktor teman

Berteman atau berinteraksi dengan pemain judi menjadi faktor seseorang 
untuk tertarik melakukan judi kartu remi. Pada awalnya mereka mengenal judi melalui interaksi dengan teman yang suka dengan judi. Fenomena ini dapat dijelaskan dengan teori Sutherland yang mengatakan bahwa criminal behavior is learned and in interaction with other persons in a process of communication (Nicholson \& Higgins, 2017:11). Artinya adalah perilaku kriminal dapat dipelajari dengan interaksi dengan orang lain dalam proses komunikasi. Maka dengan adanya komunikasi tentang judi kartu remi bersama teman maka lambat laun mereka dapat terpengaruh untuk melakukan permainan judi kartu remi.

2. Faktor waktu luang

Faktor kedua banyaknya waktu luang pada malam hari juga membuat masyarakat melakukan judi karena mereka akan mencari kegiatan maupun hiburan, Menurut (Nisar, 2014:10) Waktu luang adalah waktu senggang setelah segala keiatan dan kebutuhan yang telah dilakukan, dimananwaktu luang merupakan waktu yang bebas yang tidak terikat dari kegiatan rutinitas yang bermanfaat untuk mencari kesenangan, relaksasi dan pengembangan diri. bahkan mereka melampiaskan masalah atau hiburan stelah seharian bekerja menjadi salah satu faktor seseorang melakukan judi. Pemain judi kartu remi yang ada di Desa Sampung Dusun Medang kebanyakan bekerja di sektor pertanian. Pekerjaan tersebut membuat mereka capek dan mereka ingin melampiaskan rasa capeknya pada area judi.

3. Faktor keluarga

Faktor ketiga keluarga juga berpengaruh karena kebanyakan pemain judi adalah anak dari pemain judi lama. Menurut Soekanto (2012:386) keluarga merupakan lingkungan pertama yang berhubungan dengan anak. Melalui lingkungan keluarga seorang anak mengenal dunia sekitarnya dan pola pergaulan kehidupan sehari-hari, maka dari itu apabila seorang anak mendapatkan perhatian dan dididik dengan baik dan benar maka perilaku anak tersebut akan baik. Dan sebaliknya apabila sang anak tidak dididik dengan baik dan benar, mendapat contoh perilaku kurang baik dari keluarga, maka anak tersebut akan mengikuti contoh yang diberikan yaitu bersikap kurang baik.

4. Faktor tempat

Faktor keempat yang mendukung perkembangan judi kartu remi yang ada di Desa Sampung adalah keberadaan tempat untuk melaksanakan judi. Tempat judi yang ada oleh masyarakat di sana disebut dengan kalangan. Desa Sampung sering melakukan judi karena letak desa yang jauh dari kantor polisi dan tempatnya jauh dari dari jalan raya jadi sangat strategis untuk melakukan judi, dan ketika ada acara tempat judi juga disediakan oleh pemilik acara. Hal ini sependapat dengan apa yang dikatakan oleh Ghoni (2017:10) yang mengatakan para pelaku judi kartu 
remi pintar memilih tempat yang sulit diketahui oleh polisi, para pelaku judi kartu remi memilih tempat yang sepi dan selalu berpindah-berpindah tempat untuk aman melaksanakannya sedangkan pada acara mereka akan melakukannya di tempat sekitaran acara maupun di tempatnya yang punya acara.

Faktor yang melatarbelakangi pelaku melakukan judi kartu remi yang terbesar adalah faktor teman atau lingkungan. Mereka tertarik kerena diajak oleh teman. Awalnya mereka hanya melihat dan saling berinteraksi lambat laun mereka tertarik untuk mempelajari judi kartu remi tersebut dan setelah bisa mereka akan ikut dalam judi kartu remi. Faktor kedua adalah faktor keluarga. Keluarga merupakan tempat belajar pertama anak apabila keluarga memberikan contoh yang jelek maka anak juga akan mengikutinya. Selain faktor lingkungan dan keluarga para pemain judi kartu remi yang ada di Desa Sampung juga ada faktor lain yaitu keinginan yang timbul dari dalam diri mereka sendiri. Faktor yang timbul dari dalam diri mereka yaitu berupa uang taruhan dan untuk menyalurkan hobi mereka.

\section{Ucapan Terima Kasih}

Terima kasih kepada semua pihak yang telah mendukung penulisan artikel ini. Selanjutnya kami ucapkan terima kasih kepada redaksi Jurnal Dimensia yang telah menerbitkan tulisan ini.

\section{Daftar Pustaka}

Azwar, Saifuddin. 2015. Metode Penelitian. Yogyakarta: Pustaka Belajar.

Ghoni, Abdul. 2017. Fenomena Perjudian Sabung Ayam di Masyarakat Kampung Galian Kumejing Desa Sukamurni, Kecamatan Sukakarya, Kabupaten Bekasi. Skripsi diterbitkan. Yogyakarta: Fakultas IImu Sosial Universitas Negeri Yogyakarta. Dari. http://eprints.uny.ac.id/53337/5/RIN GKASAN\%2013413241008.pdf

Kartono, Kartini. 2014. Patologi Sosial. Jakarta: PT Raja Grafindo Persad

Miles, Mathew B \& Huberman, A.M. 2014. Analisis Data Kualitatif Buku Sumbet Tentang Metode-Metode Baru. Jakarta: UI PRESS.

Moleong, L.J. 2004. Metodologi Penelitian Kualitatif. Bandung: PT Remaja Rosdakarya.

Nasution. 2001. Metode Research Penelitian IImian (Volume 4). Jakarta: PT Bumi Aksara Nicholson \& Higgins. 2017. Social Structure Social Learning Theory: Preventing Crime And Violence, (Online),(http://www.springer.com), diakses tanggal 8 Februari 2019.

Nisar, Fachru.2014. Pemanfaatan Waktu Luang Mahasiswa. Skripsi diterbitkan. Makasar: Fakultas IImu Sosial Dan IImu Politik Universitas Hasanuddin. Dari. http://repository.unhas.ac.id/bitstrea $\mathrm{m} /$ handle/123456789/10022/SKRIP SI\%20FACHRUN\%20NISAR.pdf?s equence=1. Diakses 25 November 2019.

Soehartono, Irawan. 2008. Metode Penelitian Sosial: Suatu Taktik Penelitian Bidang Kesejahteraan Sosial dan IImu Sosial Lainnya. Bandung: PT Remaja Rosdakarya.

Soekanto, Soerjono. 2012. Sosiologi Suatu Pengantar. Jakarta: PT Raja Grafindo Persada.

Sugiyono. 2015. Metode Penelitian Pendidikan Kuantitatif, Kualitatif dan $R$ \& $D$. Bandung: Penerbit Alfabeta.

Fenomena Judi Kartu Remi di Dusun Medang Desa Sampung Kecamatan Sampung Kabupaten Ponorogo | Prima Andika Saputra, I Dewa Putu Eskasasnanda dan Sukamto 
Dimensia: Jurnal Kajian Sosiologi | Vol 9 No 2 | pISSN: 1978 -192X elSSN: 2654-9344

Undang-Undang Hukum Pidana pasal 303 ayat 3 tentang perjudian. (Online), http://wcw.cs.ui.ac.id/repository/dok umen/lihat/11205.pdf. Diakses 4 Februari 2019 